\title{
A Mini Overview of Isolation, Characterization and Application of Amniotic Fluid Stem Cells
}

\author{
Shiva Gholizadeh-Ghalehaziz ${ }^{1}$, Raheleh Farahzadi ${ }^{2}$, Ezzatollah Fathi ${ }^{3}$, Maryam Pashaiasl ${ }^{4}$ \\ ${ }^{1}$ Department of Molecular Medicine, School of Advanced Medical Sciences, \\ ${ }^{2}$ Stem Cell Research Center, Tabriz University of Medical Sciences, Tabriz, Iran \\ ${ }^{3}$ Department of Clinical Sciences, Faculty of Veterinary Medicine, University of Tabriz, Iran \\ ${ }^{4}$ Department of Reproductive Medicine, Tabriz University of Medical Sciences, Tabriz, Iran
}

\begin{abstract}
Amniotic fluid represents rich sources of stem cells that can be used in treatments for a wide range of diseases. Amniotic fluid- stem cells have properties intermediate between embryonic and adult mesenchymal stem cells which make them particularly attractive for cellular regeneration and tissue engineering. Furthermore, scientists are interested in these cells because they come from the amniotic fluid that is routinely discarded after birth. In this review we give a brief introduction of amniotic fluid followed by a description of the cells present within this fluid and aim to summarize the all existing isolation methods, culturing, characterization and application of these cells. Finally, we elaborate on the differentiation and potential for these cells to promote regeneration of various tissue defects, including fetal tissue, the nervous system, heart, lungs, kidneys, bones, and cartilage in the form of table.
\end{abstract}

Keywords: Amniotic fluid, Amniotic fluid- stem cells, Isolation, Differentiation, Tissue engineering

\section{Introduction}

The aim of regenerative medicine is currently underway to use the body's own cells to repair diseased or damaged tissue. The use of stem cells from different tissues for regenerative medicine applications has increased over the past few years. Amniotic fluid (AF) represents rich sources of stem cells population deriving from either the fetus or the surrounding amniotic membrane that can be used for clinical therapeutic applications in the patients who devel-

Accepted for publication August 31, 2015, Published online November 30, 2015 Correspondence to Ezzatollah Fathi

Department of Clinical Sciences, Faculty of Veterinary Medicine, University of Tabriz, 29 Bahman Street, Jamejam Avenue, Tabriz 5166616471, Iran

Tel: +98-4133392351, Fax: +98-4133392351

E-mail: ez.fathi@tabrizu.ac.ir

(a) This is an open-access article distributed under the terms of the Creative Commons Attribution Non-Commercial License (http://creativecommons.org/ licenses/by-nc/4.0/), which permits unrestricted non-commercial use, distribution, and reproduction in any medium, provided the original work is properly cited. op organ failure that have resistance to current therapies. The AF was first studied at the beginning of the 20th century (1). Initial studies have been performed in order to detect fetal abnormalities during development the fetus (2). Isolation and identification of amniotic fluid- stem cells (AFSCs) dating back to the early 1990's (3). The study of AFSCs has received significant attention of late for several reasons. First, $\mathrm{AF}$ is easily collected during the first trimester of pregnancy by scheduled amniocenteses for fetal karyotyping, prenatal diagnosis and detection a variety of genetic diseases (4). Second, expansion and storage of AFSCs is easy and achieved at minimal costs. Finally, these cells could be stored in cell banks and used in disease research, drug screening and genetic disorders.

\section{Amniotic Fluid}

Human $\mathrm{AF}$ is a protective and nourishing watery liquid that providing mechanical support during embryogenesis and is constituted of about $98 \%$ water (4). Other ingredients include electrolytes, pigments, sugars, fats, ami- 
no acids, proteins, carbohydrates, enzymes, growth factors and cells (5). This volume and composition varies throughout pregnancy $(5,6)$. After formation of the amniotic cavity, $7 \sim 8$ days after fertilization, this fluid starts to gather immediately. AF volume increases progressively and is then completely surrounding the embryo after 4 weeks of pregnancy. The average volume is $270 \mathrm{ml}$ at week 16 which increases to $400 \mathrm{ml}$ at week 20 of pregnancy and $800 \mathrm{ml}$ at birth (5). At the beginning of pregnancy, the amniotic osmolarity is similar to the fetal plasma. After keratinization of the fetal skin, which usually occurs at week 24 of pregnancy, amniotic osmolarity decreases relatively to maternal or fetal plasma, mainly due to the inflow of fetal urine (7). Additional investigations have been recently focused on the cellular and molecular properties of amniotic derived cells and their potential use in preclinical models and in cell therapies (4).

\section{Isolation and culturing of AFSCs}

There are three major protocols for isolation of AFSCs from human amniotic fluid. The first one is based on single-stage method (8). In this method AF collected from second-trimester amniocentesis is centrifuged. The number of cells is counted by hemocytometer and mixed with an equal volume of culture medium, usually Dulbecco's Modified Eagle Medium (DMEM) supplemented with Fetal Bovine Serum (FBS) and the cells allowed to adhere to a plastic culture plate at $10^{4}$ cells $/ \mathrm{cm}^{2}$ and incubated overnight at $37^{\circ} \mathrm{C}$ under $5 \% \mathrm{CO}_{2}$ (9). Culture medium is changed after $3 \sim 5$ days to remove non adherent cells and twice weekly thereafter. The primary cells are cultured for 4 5 days until they reached confluence and are defined as passage " 0 ". In this step the heterogeneous morphological cell population appears and after several sub-culturing the fibroblastic like cells was dominated. The cells typically reach confluence in 4 to 6 days and the remaining cells are cryopreserved in cryopreservation media (10\% dimethylsulfoxide, $90 \% \mathrm{FBS}$ ), frozen at $-80^{\circ} \mathrm{C}$ for $24 \mathrm{~h}$, and stored in liquid nitrogen the next day. The second one is immunoselection based on surface antigens. Ditadi was the first researcher to show that the c-Kit population cells extracted from the $\mathrm{AF}$ do have hematopoietic potential (10). At this time, Atala et al. (2) and Schmidt et al. (11) isolated CD117 positive cells by c-kit (a rabbit polyclonal antibody to CD117) and CD133 positive cells by CD133 magnetic beads, respectively. Their study showed these cells can be easily expanded in cultures and subpopulation of CD133 positive exhibited similar characteristics of mesenchymal progenitors cells (11). Following these studies, Arnhold et al. sorted CD117 positive cells by magnetic associated cell sorting. They indicated that the percentage of CD117 positive cells was $3.2 \pm 1.03 \%$ of the whole cell population and demonstrated that these cells could differentiate to adipogenic, osteogenic, myogenic and neurogenic lineage (12). The third one is the two-stage culture protocol established by Tsai et al., using nonadhering AF cells of the primary amniocytes culture to isolate AFSCs. In this protocol, nonadhering AF cells are collected from supernatant of AFCs that cultured in serum-free changes medium (first stage). Then collected cells are plated for AFSCs culturing after the completion of fetal chromosome analysis (second stage) (13). This method has some advantages over the others. Major advantage of this culture protocol comparing to the other two is that instead of the adhering cells derived in AF it isolates from the nonadhering cells, which is being left in the incubator without any added nutrition for $7 \sim 10$ days (13). As mentioned two-stage method is more superior compared to other methods, the use of this method have been proposed.

\section{Characterization and application of AFSCs}

The AFSCs are mainly composed of three heterogeneous groups of adherent cells, calcified based on their growth, morphological and biochemical characteristics that derived from the three germ layers (14). Epithelioid (E-type) cells that are cuboidal to columnar, derived from the fetal skin and urine, AF (AF-type) cells are originating from fetal membranes, and fibroblastic (F-type) cells are generated mainly from fibrous connective tissue. The percentage of these cells is $33.7 \%, 60.8 \%$ and $5.5 \%$. Some studies have reported that AFSCs can be easily obtained from a small amount of $\mathrm{AF}(4,15)$. Like other mesenchymal stem cells (MSCs), the AFSCs expressed CD73, CD90, CD105, CD29, CD166, CD49e, CD58, CD44 and HLA-ABC antigens and are negative for the hematopoietic markers such as CD14, CD34, CD45 and CD133, the endothelial marker such as CD31, and the HLA-DR antigen (Fig. 1) (4). These cells are able to differentiate along adipogenic, osteogenic, myogenic, endothelial, neurogenic and hepatic pathways (Table 1) (16-19). Additionally, the majority of these cells expressed the pluripotency markers such as the octamer binding protein 3/4 (Oct-3/4), the homebox transcription factor Nanog, and the stage-specific embryonic antigen 4 (SSEA-4) (20, 21). Similar to MSCs, AFSCs express MHC II at a very low level. Unlike human MSCs that are telomerase negative, low to moderate levels of the enzyme have been described in $\operatorname{AFSCs}(5,22)$. Telomerase 
is an enzyme that maintains telomere sequences at chromosomal ends (23). Telomeres consist of TTAGGG repeats protect the ends of chromosomes from end-to-end fusion,

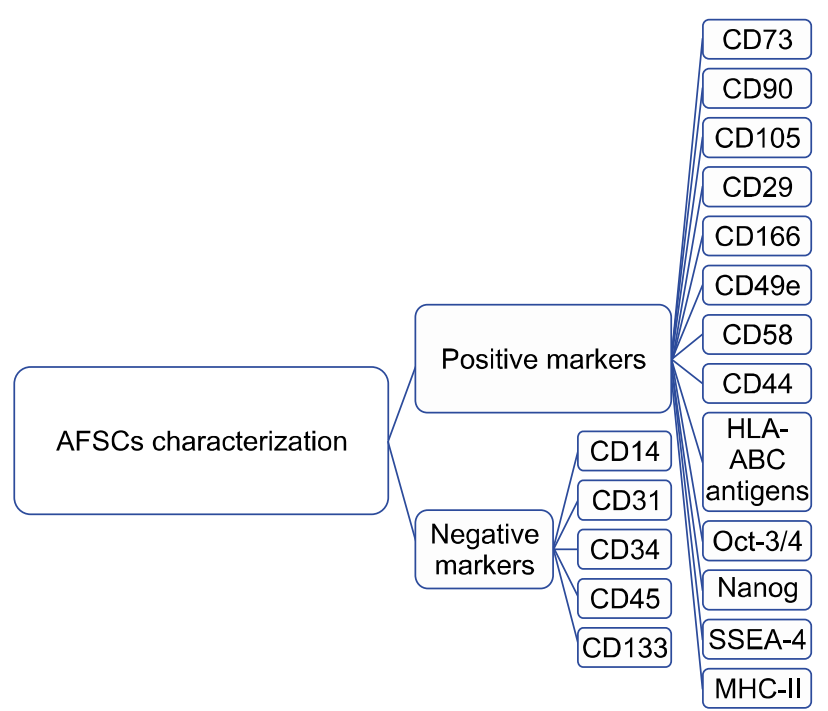

Fig. 1. Diagram for AFSCs characterization. recombination and deterioration (5). The presence of telomerase activity in both cultured and uncultured cells was found in 1999 (24). Another interesting finding have shown the presence of a population of Oct-4-positive cells in AF (25). AFSCs also express vimentin and alkaline phosphatase, which are markers of pluripotent stem cells $(5,26)$. Like other MSCs, AFSCs are attractive candidates for clinical applications, which were reviewed in Table 2. For instance some reports indicated that the AF can be a reliable and practical source of cells for the engineering of select fetal tissue constructs $(27,28)$. Another clinical application of AFSCs is the use as produce mineralized bioengineered constructs in vivo, functional repair of bone defects and bone engineering (2, 29-31), Neural tissue regeneration and nerve myelination (32-35), lung epithelial regeneration $(36,37)$, cardiac regeneration $(38,39)$ and kidney regeneration (21).

\section{Conclusion}

Like other MSCs, AFSCs have advantages such as rapid

Table 1. Some researches on differentiation potential of AFSCS

\begin{tabular}{|c|c|c|c|c|}
\hline Author names & $\begin{array}{c}\text { Year of } \\
\text { publication }\end{array}$ & Title of publication & Type of differentiation & Main results \\
\hline McLaughlin et al. & 2006 & $\begin{array}{l}\text { Stable expression of a neuronal } \\
\text { dopaminergic progenitor phe- } \\
\text { notype in cell lines derived } \\
\text { from human AFSCs }\end{array}$ & $\begin{array}{l}\text { Neural dupaminergic } \\
\text { differentiation }\end{array}$ & $\begin{array}{l}\text { They reported that AFSCs }{ }^{1} \text { are primarily com- } \\
\text { posed of a population of progenitors with a } \\
\text { phenotype similar to that of committed dop- } \\
\text { aminergic neurons (18) }\end{array}$ \\
\hline Perin et al. & 2007 & Renal differentiation of AFSCs & Renal differentiation & $\begin{array}{l}\text { AFSCs may represent a potentially limitless } \\
\text { source of ethically neutral, unmodified plu- } \\
\text { ripotential cells for kidney regeneration (19) }\end{array}$ \\
\hline Carraro et al. & 2008 & $\begin{array}{l}\text { Human AFSCs can integrate and } \\
\text { differentiate into epithelial lung } \\
\text { lineages }\end{array}$ & $\begin{array}{l}\text { Epithelial lung } \\
\text { lineages } \\
\text { differentiation }\end{array}$ & $\begin{array}{l}\text { Human AFSCs can undergo lung-specific line- } \\
\text { age differentiation and that these cells pos- } \\
\text { sess a certain level of plasticity in response } \\
\text { to different types of lung damage (36) }\end{array}$ \\
\hline Donaldson et al. & 2009 & $\begin{array}{l}\text { Human AFSCs do not differ- } \\
\text { entiate into dopamine neurons } \\
\text { in vitro or after transplantation } \\
\text { in vivo }\end{array}$ & $\begin{array}{l}\text { Neural dupaminergic } \\
\text { differentiation }\end{array}$ & $\begin{array}{l}\text { AFSCs express specific markers of neural pro- } \\
\text { genitors and immature dopamine neurons, } \\
\text { but were unable to fully differentiate into } \\
\text { dopamine neurons in vitro or in vivo (17) }\end{array}$ \\
\hline Ditadi et al. & 2010 & $\begin{array}{l}\text { Human and murine } \mathrm{AF}^{2} \mathrm{CKit}+\mathrm{Lin}- \\
\text { cells display hematopoietic } \\
\text { activity }\end{array}$ & $\begin{array}{l}\text { Erythroid, myeloid, } \\
\text { and lymphoid } \\
\text { lineages }\end{array}$ & $\begin{array}{l}\text { Under appropriate differentiation conditions, } \\
\text { AFSCs were able to generate all the blood } \\
\text { lineages (myeloid, erythroid and lymphoid } \\
\text { colonies) (10) }\end{array}$ \\
\hline Hauser et al. & 2010 & $\begin{array}{l}\text { Stem cells derived from human } \\
\text { AF contribute to acute kidney } \\
\text { injury recovery }\end{array}$ & Renal differentiation & $\begin{array}{l}\text { They reported that hAFSCs may provide an } \\
\text { alternative source of stem cells for the treat- } \\
\text { ment of acute kidney injury (16) }\end{array}$ \\
\hline Peister et al. & 2011 & $\begin{array}{l}\text { Cell sourcing for bone tissue } \\
\text { engineering: AFSCs have a } \\
\text { delayed, robust differentiation } \\
\text { compared to MSCs }\end{array}$ & $\begin{array}{l}\text { Osteogenic } \\
\text { differentiation }\end{array}$ & $\begin{array}{l}\text { Stem cell source can dramatically influence } \\
\text { the magnitude and rate of osteogenic differ- } \\
\text { entiation in vitro ( } 27)\end{array}$ \\
\hline
\end{tabular}

1: Amniotic fluid stem cells, 2: Amniotic fluid. 
Table 2. Some researches on application of AFSCs

\begin{tabular}{|c|c|c|c|c|}
\hline $\begin{array}{l}\text { Author } \\
\text { names }\end{array}$ & $\begin{array}{l}\text { Year of } \\
\text { publication }\end{array}$ & Title of publication & Application & Main results \\
\hline $\begin{array}{l}\text { Kaviani } \\
\text { et al. }\end{array}$ & 2001 & $\begin{array}{l}\text { The } \mathrm{AF}^{3} \text { as a source of cells for } \\
\text { fetal tissue engineering }\end{array}$ & $\begin{array}{l}\text { Fetal tissue } \\
\text { reconstruction }\end{array}$ & $\begin{array}{l}\text { They seeded subpopulation of } \mathrm{MSCs}^{4} \text { from the AF onto } \\
\text { a polyglycolic acid polymer/poly-4-hydroxybutyrate scaf- } \\
\text { fold and reported that these cells were able to attach } \\
\text { firmly to the scaffolds and form confluent layers with no } \\
\text { evidence of cell (23) }\end{array}$ \\
\hline $\begin{array}{l}\text { Kunisaki } \\
\text { et al. }\end{array}$ & 2006 & $\begin{array}{l}\text { Fetal cartilage engineering from } \\
\text { amniotic mesenchymal pro- } \\
\text { genitor cells }\end{array}$ & Tissue engineering & $\begin{array}{l}\text { AF could be a good cell source for tissue engineered dia- } \\
\text { phragmatic reconstruction }(24)\end{array}$ \\
\hline $\begin{array}{l}\text { De Coppi } \\
\text { et al. }\end{array}$ & 2007 & $\begin{array}{l}\text { Isolation of amniotic stem cell } \\
\text { lines with potential for therapy }\end{array}$ & Bone mineralization & $\begin{array}{l}\text { Implantation of } \mathrm{AFSCs}^{5} \text { into an immunodeficient mouse } \\
\text { cause to production of mineralized tissue in vivo (2) }\end{array}$ \\
\hline $\begin{array}{l}\text { Cipriani } \\
\text { et al. }\end{array}$ & 2007 & $\begin{array}{l}\text { Mesenchymal cells from human } \\
\text { amniotic fluid survive and mi- } \\
\text { grate after transplantation into } \\
\text { adult rat brain }\end{array}$ & $\begin{array}{l}\text { Regeneration of } \\
\text { neural tissue }\end{array}$ & $\begin{array}{l}\text { Cipriani et al. noticed AFSCs grafted cells tended to mi- } \\
\text { grate towards injured brain regions and differentiated in- } \\
\text { to neurons. They suggested the amniotic fluid could be } \\
\text { an alternative source for MSCs (28) }\end{array}$ \\
\hline $\begin{array}{l}\text { Pan } \\
\text { et al. }\end{array}$ & 2007 & $\begin{array}{l}\text { Post-injury regeneration in rat } \\
\text { sciatic nerve facilitated by neu- } \\
\text { rotrophic factors secreted by } \\
\text { AF MSCs }\end{array}$ & $\begin{array}{l}\text { Regeneration } \\
\text { sciatic nerve }\end{array}$ & $\begin{array}{l}\text { AFSCs could increase nerve degeneration due to the neu- } \\
\text { rotrophic factors secretion (29) }\end{array}$ \\
\hline $\begin{array}{l}\text { Carraro } \\
\text { et al. }\end{array}$ & 2008 & $\begin{array}{l}\text { Human AFSCs can integrate and } \\
\text { differentiate into epithelial lung } \\
\text { lineages }\end{array}$ & $\begin{array}{l}\text { Lung epithelial } \\
\text { regeneration }\end{array}$ & $\begin{array}{l}\text { AFSCs transplantation into an injured lung cause to pul- } \\
\text { monary lineage differentiation (32) }\end{array}$ \\
\hline $\begin{array}{l}\text { Chenge } \\
\text { et al. }\end{array}$ & 2010 & $\begin{array}{l}\text { Enhancement of regeneration } \\
\text { with glia cell line-derived neu- } \\
\text { rotrophic factor-transduced hu- } \\
\text { man AF MSCs after sciatic nerve } \\
\text { crush injury }\end{array}$ & $\begin{array}{l}\text { Peripheral nerve } \\
\text { regeneration }\end{array}$ & $\begin{array}{l}\text { They embedded AFSCs and glial cells in matrigel and } \\
\text { transplanted in to the injured sciatic nerve of rat and in } \\
\text { dicated that AFSCs promoted nerve regeneration (30) }\end{array}$ \\
\hline $\begin{array}{l}\text { Pan } \\
\text { et al. }\end{array}$ & 2009 & $\begin{array}{l}\text { Combination of G-CSF }{ }^{6} \text { admin- } \\
\text { istration and human AF MSCs } \\
\text { transplantation promotes pe- } \\
\text { ripheral nerve regeneration }\end{array}$ & $\begin{array}{l}\text { Peripheral nerve } \\
\text { regeneration }\end{array}$ & $\begin{array}{l}\text { They embedded AFSCs in fibrin glue and delivered to the } \\
\text { injured sciatic nerve. Increased nerve myelination and } \\
\text { improved motor function were observed in AFS trans- } \\
\text { planted (31) }\end{array}$ \\
\hline $\begin{array}{l}\text { Yeh } \\
\text { et al. }\end{array}$ & 2010 & $\begin{array}{l}\text { Cellular cardiomyoplasty with } \\
\text { human AFSCs: in vitro and in } \\
\text { vivo studies }\end{array}$ & $\begin{array}{l}\text { Cellular car } \\
\text { diomyoplasty }\end{array}$ & $\begin{array}{l}\text { AFSCs induce angiogenesis at the injured site, have car- } \\
\text { diomyogenic potential, and may be used as a new cell } \\
\text { source for cellular cardiomyoplasty (34) }\end{array}$ \\
\hline $\begin{array}{l}\text { Yeh } \\
\text { et al. }\end{array}$ & 2010 & $\begin{array}{l}\text { Cardiac repair with injectable } \\
\text { cell sheet fragments of human } \\
\text { AFSCs in an immune-sup } \\
\text { pressed rat model }\end{array}$ & $\begin{array}{l}\text { Cardiac } \\
\text { regeneration }\end{array}$ & $\begin{array}{l}\text { Transplantation of AFSCs sheet fragments stimulated a sig } \\
\text { nificant increase in vascular density, improved wall } \\
\text { thickness and a reduction in the infarct size (35) }\end{array}$ \\
\hline $\begin{array}{l}\text { Peterson } \\
\text { et al. }\end{array}$ & 2010 & $\begin{array}{l}\text { Tissue-engineered lungs for in } \\
\text { vivo implantation }\end{array}$ & Lung regeneration & $\begin{array}{l}\text { The results suggested that repopulation of lung matrix is } \\
\text { a viable strategy for lung regeneration (33) }\end{array}$ \\
\hline $\begin{array}{l}\text { Perin } \\
\text { et al. }\end{array}$ & 2010 & $\begin{array}{l}\text { Protective effect of human AFSCs } \\
\text { in an immunodeficient mouse } \\
\text { model of acute tubular necrosis }\end{array}$ & Kidney regeneration & $\begin{array}{l}\text { They found that injection of AFSCs into damaged kidney } \\
\text { modulate the kidney immune milieu in renal failure (17) }\end{array}$ \\
\hline $\begin{array}{l}\text { Rosa } \\
\text { et al. }\end{array}$ & 2010 & $\begin{array}{l}\text { MSCs lead to bone differentia- } \\
\text { tion when cocultured with } \\
\text { dental pulp stem }\end{array}$ & Bone engineering & $\begin{array}{l}\text { Combination of AFSCs with dental pulp stem cells may } \\
\text { provide a rich source of soluble proteins useful for bone } \\
\text { engineering purposes (25) }\end{array}$ \\
\hline $\begin{array}{l}\text { Maraldi } \\
\text { et al. }\end{array}$ & 2011 & $\begin{array}{l}\text { Human AFSCs seeded in fibroin } \\
\text { scaffold produce in vivo min- } \\
\text { eralized matrix }\end{array}$ & Bone engineering & $\begin{array}{l}\text { The results indicated the strong potential of AFSCs to pro- } \\
\text { duce mineralized bioengineered constructs in vivo (26) }\end{array}$ \\
\hline $\begin{array}{l}\text { Peister } \\
\text { et al. }\end{array}$ & 2011 & $\begin{array}{l}\text { Cell sourcing for bone tissue } \\
\text { engineering: AFSCs have a de- } \\
\text { layed, robust differentiation } \\
\text { compared to MSCs }\end{array}$ & Bone regeneration & $\begin{array}{l}\text { They investigated the cells were cultured within the po- } \\
\text { rous medical grade poly-epsiloncaprolactone (mPCL) } \\
\text { scaffolds could differentiate to osteoblastic cells and } \\
\text { concluded that the AFSCs were an effective source for } \\
\text { functional repair of bone defects ( } 27)\end{array}$ \\
\hline
\end{tabular}

3: Amniotic fluid, 4: Mesenchymal stem cells, 5: Amniotic fluid stem cells, 6: Granulocyte colony-stimulating factor. 
cell proliferation, low or negligible immunogenicity. Many of these cells seem to express some of the same pluripotency markers. All of these features make them valuable for potential therapy applications. Thus far they have been used in pre-clinical settings to treat a variety of diseases such as osteogenesis imperfecta, congenital diaphragmatic hernia, Parkinson's disease and cancer with encouraging results. Finally, their usefulness for AFSCs is very likely to expand their future clinical use even further. Human AFSCs could be isolated by several methods including immunoselection method based on surface antigens, single-stage and two-stage methods. Two-stage method has some advantages over the others. For example this method doesn't interfere with the normal culture process for fetal karyotyping and also illustrated their ability to successfully differentiate into osteocyte, adipocyte and etc in vitro. As two-stage method is more superior compared to other methods, the use of this method have been proposed.

\section{Acknowledgments}

The authors wish to thank staff members of Tabriz University of Medical Sciences and University of Tabriz for their contributions.

\section{Potential Conflict of Interest}

None of the authors have any conflicts of interest to declare.

\section{References}

1. Underwood MA, Gilbert WM, Sherman MP. Amniotic fluid: not just fetal urine anymore. J Perinatol 2005;25:341348

2. De Coppi P, Bartsch G Jr, Siddiqui MM, Xu T, Santos CC, Perin L, Mostoslavsky G, Serre AC, Snyder EY, Yoo JJ, Furth ME, Soker S, Atala A. Isolation of amniotic stem cell lines with potential for therapy. Nat Biotechnol 2007;25: 100-106

3. Perin L, Sedrakyan S, Da Sacco S, De Filippo R. Characterization of human amniotic fluid stem cells and their pluripotential capability. Methods Cell Biol 2008;86:85-99

4. Roubelakis MG, Trohatou O, Anagnou NP. Amniotic fluid and amniotic membrane stem cells: marker discovery. Stem Cells Int 2012;2012:107836

5. Eslaminejad MB, Jahangir S. Amniotic fluid stem cells and their application in cell-based tissue regeneration. Int $\mathrm{J}$ Fertil Steril 2012;6:147-156

6. Cananzi M, Atala A, De Coppi P. Stem cells derived from amniotic fluid: new potentials in regenerative medicine. Reprod Biomed Online 2009;18 Suppl 1:17-27

7. Ghionzoli M, Cananzi M, Zani A, Rossi CA, Leon FF, Pierro A, Eaton S, De Coppi P. Amniotic fluid stem cell migration after intraperitoneal injection in pup rats: implication for therapy. Pediatr Surg Int 2010;26:79-84

8. Steigman SA, Fauza DO. Isolation of mesenchymal stem cells from amniotic fluid and placenta. Curr Protoc Stem Cell Biol 2007; Chapter 1:Unit 1E.2

9. In 't Anker PS, Scherjon SA, Kleijburg-van der Keur C, de Groot-Swings GM, Claas FH, Fibbe WE, Kanhai HH. Isolation of mesenchymal stem cells of fetal or maternal origin from human placenta. Stem Cells 2004;22:1338-1345

10. Ditadi A, de Coppi P, Picone O, Gautreau L, Smati R, Six E, Bonhomme D, Ezine S, Frydman R, Cavazzana-Calvo $M$, André-Schmutz I. Human and murine amniotic fluid c-Kit+Lin- cells display hematopoietic activity. Blood 2009;113:3953-3960

11. Schmidt D, Achermann J, Odermatt B, Breymann C, Mol A, Genoni M, Zund G, Hoerstrup SP. Prenatally fabricated autologous human living heart valves based on amniotic fluid derived progenitor cells as single cell source. Circulation 2007;116(11 Suppl):I64-I70

12. Cananzi M, De Coppi P. CD117(+) amniotic fluid stem cells: state of the art and future perspectives. Organogenesis 2012;8:77-88

13. Tsai MS, Lee JL, Chang YJ, Hwang SM. Isolation of human multipotent mesenchymal stem cells from second-trimester amniotic fluid using a novel two-stage culture protocol. Hum Reprod 2004;19:1450-1456

14. Roubelakis MG, Pappa KI, Bitsika V, Zagoura D, Vlahou A, Papadaki HA, Antsaklis A, Anagnou NP. Molecular and proteomic characterization of human mesenchymal stem cells derived from amniotic fluid: comparison to bone marrow mesenchymal stem cells. Stem Cells Dev 2007;16:931952

15. Roubelakis MG, Bitsika V, Zagoura D, Trohatou O, Pappa KI, Makridakis M, Antsaklis A, Vlahou A, Anagnou NP. In vitro and in vivo properties of distinct populations of amniotic fluid mesenchymal progenitor cells. J Cell Mol Med 2011;15:1896-1913

16. Hauser PV, De Fazio R, Bruno S, Sdei S, Grange C, Bussolati B, Benedetto C, Camussi G. Stem cells derived from human amniotic fluid contribute to acute kidney injury recovery. Am J Pathol 2010;177:2011-2021

17. Donaldson AE, Cai J, Yang M, Iacovitti L. Human amniotic fluid stem cells do not differentiate into dopamine neurons in vitro or after transplantation in vivo. Stem Cells Dev 2009;18:1003-1012

18. McLaughlin D, Tsirimonaki E, Vallianatos G, Sakellaridis N, Chatzistamatiou T, Stavropoulos-Gioka C, Tsezou A, Messinis I, Mangoura D. Stable expression of a neuronal dopaminergic progenitor phenotype in cell lines derived from human amniotic fluid cells. J Neurosci Res 2006;83: 1190-1200

19. Perin L, Giuliani S, Jin D, Sedrakyan S, Carraro G, Habibian R, Warburton D, Atala A, De Filippo RE. Renal differentiation of amniotic fluid stem cells. Cell Prolif 2007;40:936-948

20. Klemmt PA, Vafaizadeh V, Groner B. The potential of 
amniotic fluid stem cells for cellular therapy and tissue engineering. Expert Opin Biol Ther 2011;11:1297-1314

21. Perin L, Sedrakyan S, Giuliani S, Da Sacco S, Carraro G, Shiri L, Lemley KV, Rosol M, Wu S, Atala A, Warburton D, De Filippo RE. Protective effect of human amniotic fluid stem cells in an immunodeficient mouse model of acute tubular necrosis. PLoS One 2010;5:e9357

22. Zimmermann S, Voss M, Kaiser S, Kapp U, Waller CF, Martens UM. Lack of telomerase activity in human mesenchymal stem cells. Leukemia 2003;17:1146-1149

23. Karlmark KR, Freilinger A, Marton E, Rosner M, Lubec G, Hengstschläger M. Activation of ectopic Oct-4 and Rex-1 promoters in human amniotic fluid cells. Int $\mathrm{J}$ Mol Med 2005;16:987-992

24. Kim J, Lee Y, Kim H, Hwang KJ, Kwon HC, Kim SK, Cho DJ, Kang SG, You J. Human amniotic fluid-derived stem cells have characteristics of multipotent stem cells. Cell Prolif 2007;40:75-90

25. DiGiulio DB, Romero R, Amogan HP, Kusanovic JP, Bik EM, Gotsch F, Kim CJ, Erez O, Edwin S, Relman DA. Microbial prevalence, diversity and abundance in amniotic fluid during preterm labor: a molecular and culture-based investigation. PLoS One 2008;3:e3056

26. Prusa AR, Marton E, Rosner M, Bernaschek G, Hengstschläger M. Oct-4-expressing cells in human amniotic fluid: a new source for stem cell research? Hum Reprod 2003; 18:1489-1493

27. Kaviani A, Perry TE, Dzakovic A, Jennings RW, Ziegler MM, Fauza DO. The amniotic fluid as a source of cells for fetal tissue engineering. J Pediatr Surg 2001;36:16621665

28. Kunisaki SM, Jennings RW, Fauza DO. Fetal cartilage engineering from amniotic mesenchymal progenitor cells. Stem Cells Dev 2006;15:245-253

29. De Rosa A, Tirino V, Paino F, Tartaglione A, Mitsiadis T, Feki A, d'Aquino R, Laino L, Colacurci N, Papaccio G. Amniotic fluid-derived mesenchymal stem cells lead to bone differentiation when cocultured with dental pulp stem cells. Tissue Eng Part A 2011;17:645-653

30. Maraldi T, Riccio M, Resca E, Pisciotta A, La Sala GB, Ferrari A, Bruzzesi G, Motta A, Migliaresi C, Marzona L, De Pol A. Human amniotic fluid stem cells seeded in fibroin scaffold produce in vivo mineralized matrix. Tissue Eng Part A 2011;17:2833-2843
31. Peister A, Woodruff MA, Prince JJ, Gray DP, Hutmacher DW, Guldberg RE. Cell sourcing for bone tissue engineering: amniotic fluid stem cells have a delayed, robust differentiation compared to mesenchymal stem cells. Stem Cell Res 2011;7:17-27

32. Cipriani S, Bonini D, Marchina E, Balgkouranidou I, Caimi L, Grassi Zucconi G, Barlati S. Mesenchymal cells from human amniotic fluid survive and migrate after transplantation into adult rat brain. Cell Biol Int 2007;31:845850

33. Pan HC, Cheng FC, Chen CJ, Lai SZ, Lee CW, Yang DY, Chang $\mathrm{MH}$, Ho SP. Post-injury regeneration in rat sciatic nerve facilitated by neurotrophic factors secreted by amniotic fluid mesenchymal stem cells. J Clin Neurosci 2007; 14:1089-1098

34. Cheng FC, Tai MH, Sheu ML, Chen CJ, Yang DY, Su HL, Ho SP, Lai SZ, Pan HC. Enhancement of regeneration with glia cell line-derived neurotrophic factor-transduced human amniotic fluid mesenchymal stem cells after sciatic nerve crush injury. J Neurosurg 2010;112:868-879

35. Pan HC, Chen CJ, Cheng FC, Ho SP, Liu MJ, Hwang SM, Chang $\mathrm{MH}$, Wang YC. Combination of G-CSF administration and human amniotic fluid mesenchymal stem cell transplantation promotes peripheral nerve regeneration. Neurochem Res 2009;34:518-527

36. Carraro G, Perin L, Sedrakyan S, Giuliani S, Tiozzo C, Lee J, Turcatel G, De Langhe SP, Driscoll B, Bellusci S, Minoo P, Atala A, De Filippo RE, Warburton D. Human amniotic fluid stem cells can integrate and differentiate into epithelial lung lineages. Stem Cells 2008;26:2902-2911

37. Petersen TH, Calle EA, Zhao L, Lee EJ, Gui L, Raredon MB, Gavrilov K, Yi T, Zhuang ZW, Breuer C, Herzog E, Niklason LE. Tissue-engineered lungs for in vivo implantation. Science 2010;329:538-541

38. Yeh YC, Wei HJ, Lee WY, Yu CL, Chang Y, Hsu LW, Chung MF, Tsai MS, Hwang SM, Sung HW. Cellular cardiomyoplasty with human amniotic fluid stem cells: in vitro and in vivo studies. Tissue Eng Part A 2010;16:19251936

39. Yeh YC, Lee WY, Yu CL, Hwang SM, Chung MF, Hsu LW, Chang Y, Lin WW, Tsai MS, Wei HJ, Sung HW. Cardiac repair with injectable cell sheet fragments of human amniotic fluid stem cells in an immune-suppressed rat model. Biomaterials 2010;31:6444-6453 